\title{
Factors Determining the Host Range of Two Tortoise Beetles, Cassida nebulosa L. and $C$. piperata Hope (Coleoptera: Chrysomelidae) in Japan
}

\author{
Atsuhiko Nagasawa* and Kazuhiro Matsuda
}

Laboratory of Insect Science and Bioregulation, Graduate School of Agricultural Science, Tohoku University, Sendai 981-8555, Japan

\begin{abstract}
We investigated the relationship between host-plant use by two tortoise beetles, Cassida nebulosa and C. piperata, in a field and their performance under laboratory conditions. Sixteen plant species were grown in the experimental field with C. nebulosa being observed to grow on three chenopodiaceous species (Chenopodium album, C. album var. centrorubrum, and $C$. ficifolium), while $C$. piperata grew on the same three chenopodiaceous species plus three amaranthaceous species (Amaranthus blitum, A. hybridus, and A. retroflexus). Host-plant selection in the field was directly correlated to the larval growth under laboratory conditions. Thus, the two tortoise beetles selected plant species that were suitable as larval food under natural conditions. In the laboratory experiments, the survival period of adults and the number of eggs produced showed that adults have wider food ranges than larvae. Therefore, food quality is less important as a limiting factor for adults compared to larvae. In addition, the field observation showed that C. nebulosa laid eggs only on suitable host plant species, whereas $C$. piperata laid eggs on both suitable hosts and non-hosts.
\end{abstract}

Keywords: Amaranthaceae, Cassida nebulosa, Cassida piperata, chenopodiaceae, host plants, phytophagous insects, tortoise beetles.

\section{INTRODUCTION}

Various factors restrict the host range of phytophagous insects. In general, such factors include plant quality (such as chemistry, nutritional content, toughness, and architecture), plant quantity, spatial or temporal correspondence, and ecological factors (such as interspecific competition and predation or parasitism) [1]. In particular, the relationship between oviposition preference and larval growth has been a central focus in the study of insect-plant interactions [2, 3]. Many insects show a positive correlation between oviposition preference and offspring performance [4-8]. However, some insects show a weak correlation between oviposition preference and offspring performance [2,9]. For example, the lycaenid butterfly [10], willow-feeding sawfly [11] and willow beetle [12] avoid certain plants as hosts, even though these plants are suitable food for their larvae. Thus, oviposition represents a limiting factor in host-plant use.

Two tortoise beetles, Cassida nebulosa L. and C. piperata Hope, are oligophagous insects that feed on Chenopodiaceae and Amaranthaceae [13]. However, knowledge remains limited about the host preference of Japanese Cassidinae with respect to Chenopodiaceae and Amaranthaceae plant species. Thus, we studied host-plant use by these two tortoise beetles. Since species interactions are often sitespecific, studies using host plants that are allopatric with the

\footnotetext{
*Address correspondence to this author at the Laboratory of Insect Science and Bioregulation, Graduate School of Agricultural Science, Tohoku University, Sendai 981-8555, Japan;

Tel: +81-22-717-8841; Fax: +81-22-717-8842;

E-mails: atsu.nagasawa@gmail.com or atsu.nagasawa@m.tohoku.ac.jp
}

insect population cannot inform us about the actual host plant use by insects [14]. Therefore, we used Chenopodiaceae and Amaranthaceae plants that grew sympatrically with the insect population in an experimental field. We then observed how the two tortoise beetles used potential hostplants that were planted in the experimental field.

Sometimes, host-plant use under natural conditions and performance under laboratory conditions are not correlated [15]. Thus, we also studied larval and adult performance with respect to these plants under laboratory conditions to reveal limiting factors in host-plant use.

\section{MATERIALS AND METHODOLOGY}

\section{Insects}

Two tortoise beetles, C. nebulosa and C. piperata, were collected from the experimental field of the Graduate School of Agricultural Science, Tohoku University, Sendai, Miyagi Prefecture, Japan. The beetles were reared on the leaves of Chenopodium album L. and C. album var. centrorubrum Makino, which were also collected from the field. In winter, adults were reared on the leaves of spinach, and larvae were reared on C. album and C. album var. centrorubrum grown in a greenhouse. These insects were reared at $24 \pm 1{ }^{\circ} \mathrm{C}$ and 16:8 h light:dark (L:D) photoperiod.

\section{Plants}

Nine plant species belonging to the Chenopodiaceae family and seven plant species belonging to the Amaranthaceae family were used. 


\section{Chenopodiaceae}

Wild plants: Chenopodium album L., C. album L. var. centrorubrum Makino, C. ficifolium Sm., and C. ambrosioides $\mathrm{L}$.

Cultivated plants: Beta vulgaris L. var. cicla L. (chard), B. vulgaris L. var. vulgaris (table beet), Bassia scoparia A. J. Scott, Salsola komarovii Iljin, and Spinacia oleracea L. (spinach).

\section{Amaranthaceae}

Wild plants: Amaranthus blitum L., A. hybridus L., A. retroflexus L., and Achyranthes bidentata Blume var. fauriei (H. Lév. et Vaniot)

Cultivated plants: A. tricolor L., Celosia cristata L., and Gomphrena globosa L.

All of the listed plants were grown in the experimental field of the Graduate School of Agricultural Science, Tohoku University, Japan.

\section{Field Study}

Host-plant use by the two tortoise beetles was studied in the experimental field during 2000 and 2001. Nine species of Chenopodiaceae and seven species of Amaranthaceae were randomly planted at the experimental site $(7 \times 14 \mathrm{~m})$. Plants were initially grown in pots and ten pots per each species were then transplanted to the experimental site at the end of May or the middle of June. In 2000, the plants were transplanted to the experimental site on June 17. In 2001, the plants were transplanted to the experimental site on May 23. Sixteen species were planted in 2001, while just 12 species were planted in 2000 because some plants failed to grow. After transplanting, the wild beetle population appered on these plants at this site. All weeds, except for the plants used for the study, were removed. The study began about one week after transplanting. Every 1 or 2 weeks, the numbers of egg patches, larvae, pupae, and adults of the two tortoise beetle species were counted. However, the eggs of $C$. piperata could not be counted because each egg was laid separately; thus, this parameter was excluded from the analysis. The investigation was carried out until early September of each year.

\section{Larval Growth}

A piece of filter paper ( $90 \mathrm{~mm}$ diameter) was placed at the bottom of a petri dish ( $90 \mathrm{~mm}$ diameter) and moistened with purified water (produced by Elgastat Option 4 water purifier, Elga, High Wycombe, UK) to maintain humidity. A test plant leaf was placed on the bottom of the petri dish. Ten larvae that had hatched within a $24-\mathrm{h}$ period were transferred to each leaf. These larvae were reared at $24 \pm 1^{\circ} \mathrm{C}$ under a 16L:8D photoperiod. The leaves were changed every 1-3 days to maintain suitability. The experiment was carried out until all larvae became adults or died. The experiment had 810 replicates for each plant.

\section{Performance of Adults on Plants}

The experiment was conducted under the same conditions as that used for the larvae experiment in the previous section. Within $24 \mathrm{~h}$ of emergence, 10 adults (reared on $C$. album or C. album var. centrorubrum throughout the larval period) were released into each petri dish. Each day, the number of survivors and eggs were counted. The experiment was carried out until all adults died or all food plants had disappeared. The experiment had 5 replicaes for each plant.

\section{Statistical Analysis}

We performed statistical analyses using R v. 3.0.2 for Mac OS X [16]. The number of larvae that survived and the performance of adults (the number of egg batches, eggs, and number of adults that survived at 30, 60, and 120 days after emergence) on 16 plant species were analyzed using the Tukey's HSD test [17] after $\log$ transformation $[\log (\mathrm{x}+$ $0.5)]$.

\section{RESULTS}

\section{Field Study}

The distribution of the two tortoise beetles for each plant in the experimental site is shown in Table 1. Cassida nebulosa was mostly found on C. album, C. album var. centrorubrum, and $C$. ficifolium. In exceptional cases, two egg batches and two larvae of $C$. nebulosa were found on $A$. bidentata var. fauriei and one larva was found on G. globosa in 2000 . However, the eggs and larvae did not grow on these plants. In comparison, C. piperata was found on all experimental plants, except $S$. komarovii and $C$. cristata. However, only the larvae from the early stages of developmant were observed on B. scoparia, A. tricolor, G. globosa, and A. bidentata var. fauriei, with none of the pupae being found on these plant species.

\section{Larval Growth}

The suitability of the experimental plants for larvae was estimated by the eclosion rate. Cassida nebulosa showed high eclosion rates on C. album, C. album var. centrorubrum, and $C$. ficifolium, whereas no adults emerged on amaranthaceous plants (Fig. 1). Cassida piperata showed high eclosion rates on $C$. album, $C$. album var. centrorubrum, $C$. ficifolium, B. scoparia, A. blitum, and A. hybridus. The survival rates on chenopodiaceous plants was similar for both tortoise beetles, whereas the survival rates on amaranthaceous plants were different (Fig. 1).

\section{Performance of Adults on Plants}

The eggs of C. nebulosa were found on C. album, C. album var. centrorubrum, C. ficifolium, and spinach. Only a few or no eggs were found on the other experimantal plants. No eggs were oviposited on amaranthaceous plants (Table 2). In comparison, most C. piperata eggs was laid on C. album var. centrorubrum, followed by A. blitum, C. album, and spinach. Only a few or no eggs of either species were found on $A$. tricolor, $C$. cristata, and $G$. globosa (Table 3). Because B. scoparia and $S$. komarovii died off during the study, beetle survival periods were indicated by the number of adults that survived at 30, 60, and 100 days after emergence. Large numbers of $C$. nebulosa survived on C. ambrosioides, C. album var. centrorubrum, B. scoparia, and chard (Table 2). Cassida nebulosa adults lived a long 


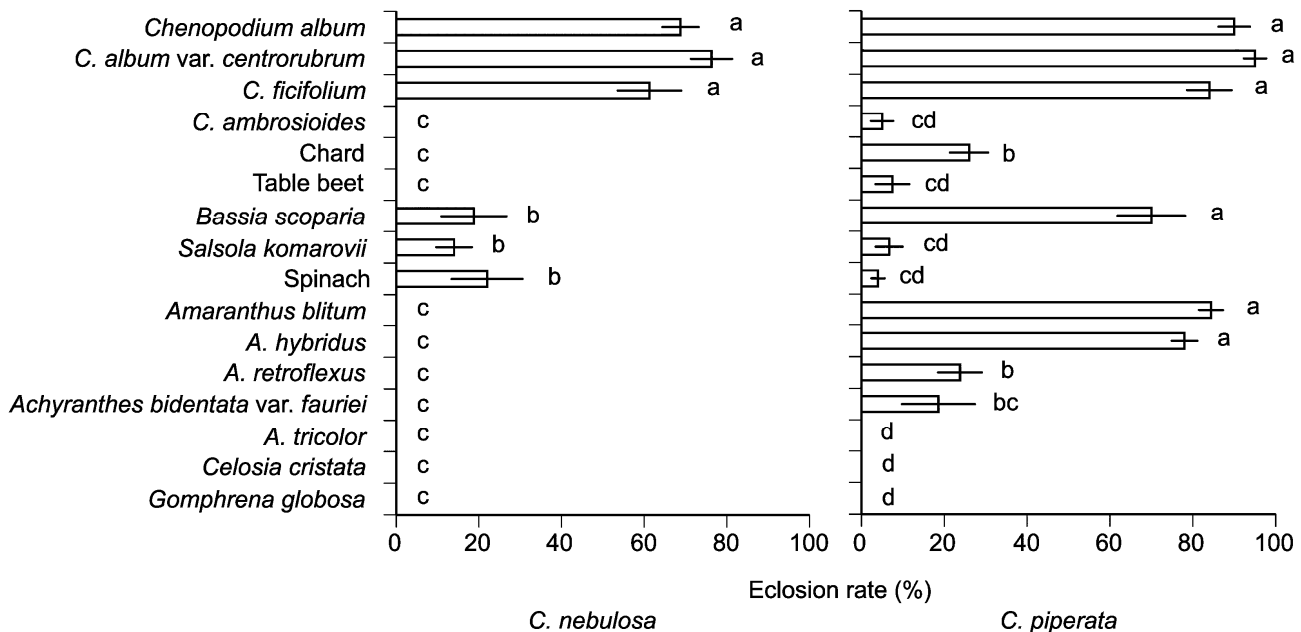

Fig. (1). Eclosion rates of two tortoise beetles on plants belonging to the Chenopodiaceae and Amaranthaceae families. Bars labeled with the same letters on the same series are not significantly different at the $5 \%$ level by the Tukey's HSD test.

Table 1. Total number of the two tortoise beetles on plants belonging to the Chenopodiaceae and Amaranthaceae families in the experimental field during the study period.

\begin{tabular}{|c|c|c|c|c|c|c|c|}
\hline Plants & \multicolumn{4}{|c|}{ No. of $C$. nebulosa } & \multicolumn{3}{|c|}{ No. of $C$. piperata } \\
\hline Chenopodium album & 20 & 303 & 15 & 12 & 56 & 1 & 13 \\
\hline C. album var. centrorubrum & 106 & 1092 & 128 & 28 & 34 & 4 & 10 \\
\hline C. ambrosioides $^{2}$ & 0 & 0 & 0 & 0 & 0 & 0 & 0 \\
\hline Chard $^{2}$ & 0 & 0 & 0 & 0 & 9 & 1 & 1 \\
\hline Table beet & 0 & 0 & 0 & 0 & 7 & 1 & 0 \\
\hline Bassia scoparia & 0 & 0 & 0 & 0 & 1 & 0 & 0 \\
\hline \multicolumn{8}{|l|}{ Amaranthaceae } \\
\hline Amaranthus blitum & 0 & 0 & 0 & 0 & 113 & 11 & 25 \\
\hline A. hybridus & 0 & 0 & 0 & 1 & 67 & 2 & 15 \\
\hline A. retroflexus & 0 & 0 & 0 & 0 & 36 & 3 & 22 \\
\hline Achyranthes bidentata var. fauriei & 2 & 2 & 0 & 0 & 13 & 0 & 3 \\
\hline A. tricolor & 0 & 0 & 0 & 0 & 15 & 0 & 3 \\
\hline 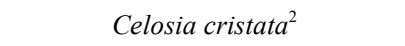 & 0 & 0 & 0 & 0 & 0 & 0 & 0 \\
\hline
\end{tabular}

2000 (29-Jun, 4-Jul, 10-Jul, 19-Jul, 1-Aug, 13-Aug, 24-Aug)

2001 (1-Jun, 8-Jun, 22-Jun, 29-Jun, 7-Jul, 13-Jul, 26-Jul, 10-Aug, 25-Aug)

${ }^{1}$ Pupae $=$ No. of prepupae + No. of pupae

${ }^{2}$ These plants were investigated in 2001 only 
Table 2. Performance of $C$. nebulosa adults on plants belonging to the Chenopodiaceae and Amaranthaceae families.

\begin{tabular}{|c|c|c|c|c|c|}
\hline \multirow{3}{*}{ Plants } & \multirow{3}{*}{$\begin{array}{l}\text { Egg Batches } \\
\left(\text { Mean } \pm \text { SE) }{ }^{1}\right.\end{array}$} & \multirow{3}{*}{$\begin{array}{c}\text { Eggs } \\
(\text { Mean } \pm \text { SE })^{1,2}\end{array}$} & \multicolumn{3}{|c|}{ Survival No. $(\text { Mean } \pm \mathrm{SE})^{1}$} \\
\hline & & & \multicolumn{3}{|c|}{ Days After Emergence } \\
\hline & & & 30 & 60 & 100 \\
\hline \multicolumn{6}{|l|}{ Chenopodiaceae } \\
\hline Chenopodium album & $21.8 \pm 7.3 \mathrm{ab}$ & $201.0 \pm 70.2 \mathrm{ab}$ & $8.8 \pm 0.7 \mathrm{a}$ & $5.8 \pm 0.6 \mathrm{ab}$ & $2.4 \pm 0.7 \mathrm{ab}$ \\
\hline C. album var. centrorubrum & $46.2 \pm 18.3 \mathrm{a}$ & $464.8 \pm 201.4 \mathrm{a}$ & $9.4 \pm 0.4 \mathrm{a}$ & $8.8 \pm 0.2 \mathrm{a}$ & $5.2 \pm 0.4 \mathrm{a}$ \\
\hline C. ficifolium & $48.4 \pm 18.3 \mathrm{a}$ & $543.6 \pm 208.9 \mathrm{a}$ & $6.8 \pm 0.6 \mathrm{a}$ & $2.4 \pm 1.0 \mathrm{bcd}$ & $0.8 \pm 0.6 \mathrm{bc}$ \\
\hline C. ambrosioides & $3.4 \pm 2.5 \mathrm{bc}$ & $18.0 \pm 12.6 \mathrm{bc}$ & $9.2 \pm 0.4 \mathrm{a}$ & $9.2 \pm 0.4 \mathrm{a}$ & $5.4 \pm 1.0 \mathrm{a}$ \\
\hline Chard & $5.6 \pm 2.5 \mathrm{abc}$ & $30.4 \pm 12.8 b c$ & $8.8 \pm 0.5 \mathrm{a}$ & $7.4 \pm 1.0 \mathrm{a}$ & $4.8 \pm 0.9 \mathrm{a}$ \\
\hline Table beet & $1.2 \pm 0.8 \mathrm{c}$ & $9.2 \pm 5.9 \mathrm{bc}$ & $6.4 \pm 1.5 \mathrm{ab}$ & $1.0 \pm 0.4 \mathrm{de}$ & $0 \mathrm{c}$ \\
\hline Bassia scoparia & $0 \mathrm{c}$ & $0 \mathrm{c}$ & $7.8 \pm 0.7 \mathrm{a}$ & $6.0 \pm 0.9 \mathrm{a}$ & $4.4 \pm 0.5 \mathrm{a}$ \\
\hline Salsola komarovii & $0 \mathrm{c}$ & $0 \mathrm{c}$ & $8.4 \pm 0.2 \mathrm{a}$ & $7.2 \pm 0.4 \mathrm{a}$ & $2.6 \pm 1.0 \mathrm{ab}$ \\
\hline Spinach & $23.8 \pm 8.4 \mathrm{ab}$ & $160.8 \pm 60.0 \mathrm{ab}$ & $7.0 \pm 0.3 \mathrm{a}$ & $4.8 \pm 0.7 \mathrm{abc}$ & $2.2 \pm 0.8 \mathrm{ab}$ \\
\hline \multicolumn{6}{|l|}{ Amaranthaceae } \\
\hline Amaranthus blitum & $0 \mathrm{c}$ & $0 \mathrm{c}$ & $5.8 \pm 0.7 \mathrm{ab}$ & $2.0 \pm 0.5 \mathrm{~cd}$ & $0 \mathrm{c}$ \\
\hline A. hybridus & $0 \mathrm{c}$ & $0 \mathrm{c}$ & $8.4 \pm 1.2 \mathrm{a}$ & $6.2 \pm 1.1 \mathrm{ab}$ & $2.0 \pm 0.8 \mathrm{ab}$ \\
\hline A. retroflexus & $0 \mathrm{c}$ & $0 \mathrm{c}$ & $0.2 \pm 0.2 \mathrm{c}$ & $0 \mathrm{e}$ & $0 \mathrm{c}$ \\
\hline Achyranthes bidentata var. fauriei & $0 \mathrm{c}$ & $0 \mathrm{c}$ & $5.2 \pm 0.7 \mathrm{ab}$ & $3.8 \pm 0.7 \mathrm{abc}$ & $0.8 \pm 0.6 \mathrm{bc}$ \\
\hline A. tricolor & $0 \mathrm{c}$ & $0 \mathrm{c}$ & $0 \mathrm{c}$ & $0 \mathrm{e}$ & $0 \mathrm{c}$ \\
\hline Celosia cristata & $0 \mathrm{c}$ & $0 \mathrm{c}$ & $0 \mathrm{c}$ & $0 \mathrm{e}$ & $0 \mathrm{c}$ \\
\hline Gomphrena globosa & $0 \mathrm{c}$ & $0 \mathrm{c}$ & $3.2 \pm 1.2 \mathrm{~b}$ & $0.2 \pm 0.2 \mathrm{e}$ & $0 \mathrm{c}$ \\
\hline
\end{tabular}

${ }^{1}$ Values followed by the same letters in each series are not signigicantly different at the $5 \%$ level by the Tukey's HSD test.

${ }^{2}$ Eggs indicate the total number of eggs in egg batches.

time on chenopodiaceous plants, except for table beet and $C$. ficifolium, even though amaranthaceous plants (except $A$. hybridus) were not suitable as food (Table 2). Compared to other plants, fewer C. piperata adults survived on C. ficifolium, chard, table beet, C. cristata, and G. globosa (Table 3).

\section{DISCUSSION}

The larvae and pupae of $C$. nebulosa were found on $C$. album, C. album var. centrorubrum, and C. ficifolium in the field. In comparison, large numbers of $C$. piperata larvae and pupae were found on C. album, C. album var. centrorubrum, $C$. ficifolium, A. blitum, A. hybridus, and A. retroflexus in the field. The existence of pupae indicates that $C$. nebulosa larvae develop on three chenopodiaceous plant species, whereas those of $C$. piperata develop on the same three chenopodiaceous plant species plus three amaranthaceous plant species. Therefore, these six species were considered to be the main host plants of the two beetle species. In addition, chard, table beet, and spinach may be potential foods for $C$. piperata, because some pupae and larvae were found on these plants. The two tortoise beetles exhibited different patterns of Chenopodiaceae and Amaranthaceae host-plant use.
In Europe, C. nebulosa grows on and harms the leaves of sugar beets [18, 19]. In Japan, although C. nebulosa eat sugar beet, only a few larvae reach adult stage on this plant (about 10\%) [20]. In addition, C. nebulosa from Hokkaido (the northern part of Japan) feed on A. bidentata [21]. However, our results showed that $C$. nebulosa was not able to grow on $A$. bidentata var. fauriei. Thus, host-plant use differs among phytophagous insect populations [22]. The case of $C$. nebulosa exemplifies this phenomenon.

In general, the oviposition preference and larval performance are the main limiting factors of the host plant use by phytophagous insects [23]. In the experimental field, the eggs of $C$. nebulosa were only observed on three Chenopodiaceae species (C. album, C. album var. centrorubrum, and C. ficifolium), with this beetle species also showing a high survival rate on this plant species in the laboratory experiment. The eggs of $C$. nebulosa were not observed on any other plant species, even though a few adults emerged or oviposited on other species in the laboratory experiment. These results show that oviposition is a primary limiting factor for the host range of $C$. nebulosa. In comparison, it was difficult to count the exact number of $C$. piperata eggs in the field which could only be approximated from the 
Table 3. Performance of $C$. piperata adults on plants belonging to Chenopodiaceae and Amaranthaceae families.

\begin{tabular}{|c|c|c|c|c|}
\hline \multirow{2}{*}{ Plants } & \multirow{2}{*}{$\begin{array}{c}\text { Eggs } \\
(\text { Mean } \pm \text { SE })^{1}\end{array}$} & \multicolumn{3}{|c|}{ Survival No. $(\text { Mean } \pm S E)^{1}$} \\
\hline & & 30 & 60 & 100 \\
\hline \multicolumn{5}{|l|}{ Chenopodiaceae } \\
\hline Chenopodium album & $1275.0 \pm 236.0 \mathrm{ab}$ & $10.0 \pm 0.0 \mathrm{a}$ & $7.4 \pm 0.6 \mathrm{a}$ & $4.6 \pm 1.0 \mathrm{ab}$ \\
\hline C. ficifolium & $929.6 \pm 448.9 \mathrm{abc}$ & $6.0 \pm 1.4 \mathrm{~b}$ & $2.8 \pm 1.1 \mathrm{~b}$ & $1.6 \pm 0.5 \mathrm{~b}$ \\
\hline C. ambrosioides & $190.0 \pm 46.1 \mathrm{bc}$ & $9.0 \pm 0.4 \mathrm{ab}$ & $8.6 \pm 0.2 \mathrm{a}$ & $6.6 \pm 0.4 \mathrm{a}$ \\
\hline Chard & $355.8 \pm 78.8 \mathrm{abc}$ & $7.2 \pm 0.2 \mathrm{ab}$ & $5.4 \pm 0.6 \mathrm{a}$ & $1.8 \pm 0.9 \mathrm{~b}$ \\
\hline Table beet & $279.6 \pm 107.9 \mathrm{bc}$ & $8.0 \pm 0.7 \mathrm{ab}$ & $4.6 \pm 0.6 \mathrm{ab}$ & $1.8 \pm 0.7 \mathrm{~b}$ \\
\hline Spinach & $1268.0 \pm 368.3 \mathrm{ab}$ & $8.6 \pm 0.6 \mathrm{ab}$ & $6.8 \pm 1.2 \mathrm{a}$ & $4.0 \pm 1.4 \mathrm{ab}$ \\
\hline \multicolumn{5}{|l|}{ Amaranthaceae } \\
\hline Amaranthus blitum & $1583.8 \pm 230.7 \mathrm{ab}$ & $9.4 \pm 0.4 \mathrm{ab}$ & $9.2 \pm 0.5 \mathrm{a}$ & $5.6 \pm 0.8 \mathrm{a}$ \\
\hline A. hybridus & $500.8 \pm 175.1 \mathrm{abc}$ & $8.8 \pm 0.2 \mathrm{ab}$ & $8.2 \pm 0.6 \mathrm{a}$ & $6.2 \pm 0.6 \mathrm{a}$ \\
\hline A. retroflexus & $433.0 \pm 94.6 \mathrm{abc}$ & $8.0 \pm 0.6 \mathrm{ab}$ & $5.4 \pm 0.5 \mathrm{a}$ & $3.2 \pm 0.6 \mathrm{ab}$ \\
\hline Achyranthes bidentata var. fauriei & $192.6 \pm 68.2 \mathrm{c}$ & $9.2 \pm 0.5 \mathrm{ab}$ & $7.6 \pm 0.7 \mathrm{a}$ & $3.6 \pm 0.6 \mathrm{ab}$ \\
\hline A. tricolor & $7.8 \pm 6.6 \mathrm{~d}$ & $7.6 \pm 0.5 \mathrm{ab}$ & $6.0 \pm 0.8 \mathrm{a}$ & $3.8 \pm 0.6 \mathrm{ab}$ \\
\hline
\end{tabular}

${ }^{1}$ Values followed by the same letters in each series are not signigicantly different at the $5 \%$ level by the Tukey's HSD test.

number of larvae, as larvae are not sufficiently mobile to move to other plants. For this reason, the number of larvae was used to estimate the oviposition preference of this species, rather than the number of eggs. Many C. piperata larvae were found on their host plants; however, many early stage larvae were also found on non-host plants. This finding indicates that $C$. piperata lays eggs on both host and nonhost plants. Therefore, $C$. piperata does not select specific plants for oviposition. After hatching, the larvae on host plants developed well, whereas those on non-host plants failed to develop. These results show that larval growth is a more important limiting factor for $C$. piperata than ovipositional selection.

We also investigated plant qualities as foods for adults in the laboratory experiment. Both species laid more eggs on host plants. However, adults also exhibited a long life and oviposition on some non-host plants. Thus, the available food range of adults is wider than that of larvae, because the adults could use plants that larvae could not grow on in the laboratory experiments. Therefore, food quality is less important for adults as the limiting factor of their host range than for larval growth or ovipositional behavior.

In addition to the direct insect-plant relationship, previous studies have indicated that external ecological factors limit the host range of phytophagous insects. Such factors include temporal and spatial availability $[24,25]$, the effect of natural enemies [12, 26-30], competition, or meteorological factors $[31,32]$. In the current study, temporal and spatial availability were not limiting factors for the insect and plant population. Other factors were not considered in this study. However, we assumed that these ecological factors were not critical limiting factors because the host ranges of the two species could be explained by the direct insect-plant relationship.

\section{CONCLUSION}

Our results showed that ovipositional selection and larval growth were affected by host-plant use. Both species showed positive correlations between oviposition preference and larval performance. However, the two tortoise beetles differed in their specificity of host plant selection. Consequently, C. nebulosa plant use was restricted by ovipositional selection, whereas $C$. piperata plant use was restricted by larval growth. The importance of ovipositional selection has been studied in detail for Lepidoptera species, since to adults and larvae use different foods [3]. The current study focused on leaf beetles [12], revealing that ovipositional selection is the important factor in determining the host range 
of some leaf beetle species that use the same food as adults and larvae.

\section{CONFLICT OF INTEREST}

The authors confirm that this article content has no conflict of interest.

\section{ACKNOWLEDGEMENTS}

Declared none.

\section{REFERENCES}

[1] Bernays EA, Chapman RF. Host-Plant Selection by Phytophagous Insects. New York: Chapman \& Hall 1994.

[2] Thompson JN. Evolutionary ecology of the relationship between oviposition preference and performance of offspring in phytophagous insects. Entomol Exp Appl 1988; 47: 3-14.

[3] Thompson JN, Pellmyr O. Evolution of oviposition behavior and host preference in Lepidoptera. Ann Rev Entomol 1991; 36: 65-89.

[4] Whitham TG. The theory of habitat selection: examined and extended using Pemphigus aphids. Am Nat 1980; 115: 449-66.

[5] Rausher MD. Population differentiation in Euphydryas editha butterflies: larval adaptation to defferent hosts. Evolution 1982; 36: 581-90.

[6] Singer MC, Ng D, Thomas CD. Heritability of oviposition preference and its relationship to offspring performance within a single insect population. Evolution 1988; 42: 977-85.

[7] Craig TP, Itami JK, Olmstead KL. A strong relationship between oviposition preference and larval performance in a shoot-galling sawfly. Ecology 1989; 70: 1691-9.

[8] Sidhu JK, Stout MJ, Blouin DC. Performance and preference of sugarcane borer, Diatraea saccharalis, on rice cultivars. Entomol Exp Appl 2013; 149: 67-76.

[9] Courtney SP, Kibota TT. Mother doesn't know best: selection of hosts by ovipositing insects, In: Bernays EA, Ed, Insect-Plant Interactions. Florida: CRC Press 1990; 161-88.

[10] Atsatt PR. Lycaenid butterflies and ants: selection for enemy-free space. Am Nat 1981; 118: 638-54.

[11] Roininen H, Tahvanainen J. Host selection and larval performance of two willow-feeding sawflies. Ecology 1989; 70: 129-36.

[12] Denno RF, Larsson S, Olmstead KL. Role of enemy-free space and plant quality in host-plant selection by willow beetles. Ecology 1990; 71: 124-37.

[13] Chujo M, Kimoto S. Systematic catalog of Japanese Chrysomelidae (Coleoptera). Pacific Insects 1961; 3: 117-202.
[14] Ballabeni P, Rahier M. Performance of leaf beetle larvae on sympatric host and non-host plants. Entomol Exp Appl 2000; 97: 175-81.

[15] Fox CW, Lalonde RG. Host confusion and the evolution of insect diet breadths. Oikos 1993; 67: 577-81.

[16] R Core Team. R: A language and environment for statistical computing. Vienna: R Foundation for Statistical Computing 2013, http://www.R-project.org/.

[17] Hsu JC. Multiple Comparisons: Theory and Methods. Florida: Chapman \& Hall/CRC 1996.

[18] Redzepagic H. Biological and ecological investigations of Cassida nebulosa L. as a basis for the establishing of its control (in SerboCroatian with English summary). Poljoprivredna Znanstvena Smotra 1984; 64: 75-87.

[19] Redzepagic H. The plants supporters and noxiousness of Cassida nebulosa L. (in Serbo-Croatian with English summary). Poljoprivredna Znanstvena Smotra 1987; 78(9): 173-9.

[20] Yasutomi K. Host selection of Cassida nebulosa Linné (in Japanese). Kontyu 1949; 17: 31-3.

[21] Yasutomi K. Contributions to the knowledge of tortoise beetles (Chrysomelidae: Cassidinae) (in Japanese). Nature \& Insects 2002; 37: 35-8.

[22] Fox LR, Morrow PA. Specialization: species property or local phenomenon? Science 1981; 211: 887-93.

[23] Schoonhoven LM, van Loon JJA, Dicke M. Insect-Plant Biology, $2^{\text {nd }}$ ed. Oxford: Oxford University Press 2005.

[24] Courtney SP. Coevolution of Pierid butterflies and their Cruciferous foodplants. IV. Crucifer apparency and Anthocharis cardamines (L.) oviposition. Oecologia 1982; 52: 258-65.

[25] Rausher MD. Host abundance, juvenile survival, and oviposition preference in Battus philenor. Evolution 1980; 34: 342-55.

[26] Ohsaki N, Saito Y. Food plant choice of Pieris butterflies as a trade-off between parasitoid avoidance and quality of plants. Ecology 1994; 75: 59-68.

[27] Gratton C, Welter SC. Does "enemy-free space" exist? Experimantal host shifts of an herbivorous fly. Ecology 1999; 80: 773-85.

[28] Yamaga Y, Ohgushi T. Preference-performance linkage in a herbivorous lady beetle: consequences of variability of natural enemies. Oecologia 1999; 119: 183-90.

[29] Ballabeni P, Wlodarczyk M, Rahier M. Does enemy-free space for eggs contribute to a leaf beetle's oviposition preference for a nutritionally inferior host plant? Funct Ecol 2001; 15: 318-24.

[30] Stamp N. Enemy-free space via host plant chemistry and dispersion: assessing the influence of tri-trophic interactions. Oecologia 2001; 128: 153-63.

[31] Futuyma DJ, Peterson SC. Genetic variation in the use of resources by insects. Ann Rev Entomol 1985; 30: 217-38.

[32] Jaenike J. Host specialisation in phytophagous insects. Ann Rev Ecol Syst 1990; 21: 243-73. 